\title{
Effect of oral administration of green tea extract in various dosage schemes on oxidative stress status of mice in vivo
}

\author{
HANA BÁRTÍKOVÁ ${ }^{1}$ \\ LENKA SKÁLOVÁ ${ }^{1}$ \\ KATEŘINA VALENTOVÁ ${ }^{2}$ \\ PETRA MATOUŠKOVÁ ${ }^{1}$ \\ BARBORA SZOTÁKOVÁ ${ }^{1}$ \\ JAN MARTIN ${ }^{1}$ \\ VOJTĚCH KVITA \\ IVA BOUŠOVÁ ${ }^{1}$ \\ ${ }^{1}$ Faculty of Pharmacy \\ Charles University in Prague \\ CZ-500 05 Hradec Králové \\ Czech Republic \\ ${ }^{2}$ Faculty of Medicine and Dentistry \\ Palacký University \\ CZ-775 15 Olomouc \\ Czech Republic
}

Accepted October 15, 2014

\begin{abstract}
Green tea is a favorite beverage and its extracts are popular components of dietary supplements. The aim of the present in vivo study was to obtain detailed information about the effect of a standard green tea extract (Polyphenon, P), at different doses, on antioxidant enzymes and oxidative stress markers in murine blood, liver, small and large intestine. In all doses, $\mathrm{P}$ improved the oxidative stress status via an increased content of plasmatic SH-groups (by 21-67\%). Regarding antioxidant enzymes in tissues, the low dose of $\mathrm{P}$ had the best positive effect as it elevated the activity of NADPH quinone reductase in liver and small intestine, thioredoxin reductase in small intestine and hepatic superoxide dismutase. Based on these facts, consumption of green tea seems to be safe and beneficial, while consumption of dietary supplements containing high doses of catechins may disturb oxidative balance by lowering the activity of thioredoxin reductase, glutathione S-transferase, glutathione reductase and superoxide dismutase.
\end{abstract}

Keywords: green tea extract, dietary supplement; flavonoids, green tea catechins, antioxidant enzymes

Aerobic organisms possess antioxidant defense systems that can cope with reactive oxygen species (ROS), including hydroxyl radicals, superoxide radicals and hydrogen peroxide. This defense system consists of antioxidant enzymes and low molecular mass substances capable of ROS scavenging (1). The most important antioxidant enzymes are superoxide dismutase (SOD), glutathione peroxidase (GPx), catalase (CAT), glutathione S-transferase (GST), NAD(P)H quinone reductase (NQO), thioredoxin reductase (TrxR) and glutathione reductase (GR), which ensures proper GPx function. Antioxidant substances include vitamins $C$ and $E$, thiol compounds and phytonutrients such as carotenoids or flavonoids (1).

Green tea catechins (i.e., epicatechin, epigallocatechin, epicatechin gallate, and epigallocatechin gallate), representing a class of flavonoids, show protective qualities against a variety of pathologies, including cardiovascular diseases, cancer, diabetes mellitus, and

\footnotetext{
* Correspondence; e-mail: Iva.Bousova@faf.cuni.cz
} 
obesity (2). Ample evidence of their beneficial effects on human health has led to the increasing popularity of food supplements, which contain catechins in high doses (3). It is therefore essential to keep in mind the possible undesired effects the catechins - such as toxicity (4), pro-oxidative effects (4) or alteration of drug-metabolizing enzymes and transporters $(2,5)$. On the other hand, the modulation of detoxifying enzymes by catechins can contribute to chemoprotection and antioxidant defense of organisms (6).

The effects of green tea catechins on oxidative stress and antioxidant enzymes described in the literature are inconsistent. Whereas some studies documented significant induction of antioxidant enzymes (e.g., NQO, GPx, CAT, SOD) via green tea catechins (6), another study showed a decrease in NQO and no changes of other antioxidant enzymes in catechin-treated rats (7). Evaluation of published reports is complicated and their comparison almost impossible due to totally different experimental conditions (differences, e.g., in animal species and strains, administered substances, dosage schemes, and route of administration). Moreover, most of the studies were focused only on one tissue (mostly blood or liver) and a complex view was lacking.

Therefore, the present in vivo study was designed to test the effect of green tea extract (in three different dosage schemes) on oxidative stress parameters and the activity of a panel of antioxidant enzymes in liver, erythrocytes, small and large intestine in mice to obtain more complex information. Polyphenon, the defined and commercially available form of green tea extract, was used in this study.

\section{EXPERIMENTAL}

\section{Chemicals and reagents}

Protease inhibitor cocktail tablets (EDTA free complete protease inhibitor cocktail tablets) were supplied by Roche (Switzerland). SOD assay kit-WST [2-(4-iodophenyl)-3-(4nitrophenyl)-5-(2,4-disulfophenyl)-2H-tetrazolium monosodium salt] was provided by Dojindo (Japan). Polyphenon 60 was a product of Sigma-Aldrich (Czech Republic). Protein standard for electrophoresis was obtained from Bio-Rad (USA). All other chemicals, which were of HPLC or analytical grade, were obtained from Sigma-Aldrich. The GST and $\beta$-actin antibodies were purchased from Abcam (UK). The NQO primary and secondary antibodies were supplied by Novus Biologicals (UK) and Santa Cruz Biotechnology (USA). Western blotting was done using a chemiluminescence kit from Santa Cruz Biotechnology (USA).

Polyphenon 60 was a product of Sigma-Aldrich (Czech Republic). Based on HPLC analysis (8) performed by our research group, the content of individual catechins in Polyphenon 60 was as follows: (-)-epicatechin $12.5 \%$, (-)-epigallocatechin $32.7 \%$, (-)-epigalocatechin gallate $41.8 \%$, and (-)-epicatechin gallate $13.0 \%$ of the total catechins, amounting to $100 \%(8)$.

\section{Experimental animals}

Male NMRI mice obtained from Medi Tox (Konárovice, Czech Republic) were housed at a temperature of $23{ }^{\circ} \mathrm{C}$ and a daily light and dark cycle of $12 \mathrm{~h}$ (light from 6:00 a.m.). 
Animals were given water ad libitum and a standard chow diet (ST-1, Velaz, Czech Republic). They were cared for and used in accordance with the Guide for the Care and Use of Laboratory Animals (Protection of Animals from Misuse Act No. 246/92, Czech Republic). The Ethical Committee of Charles University in Prague, Faculty of Pharmacy in Hradec Králové, approved all animal experimental procedures.

At 7 months of age, mice were randomly divided into 4 groups (12 mice per group). For further 4 weeks (28 days), the first group (control) was fed a standard diet without Polyphenon (P), the second group (P-H28) was fed a $0.1 \%$ P-enriched diet (high dose, $\mathrm{H}$ ), the third group (P-L28) was fed a $0.01 \%$ P-enriched diet (low dose, L). The fourth group (P-H3) consisted of mice fed the standard diet without $\mathrm{P}$ for 25 days and for consequent 3 days a $0.1 \%$ P-enriched diet (high dose, $\mathrm{H}$ ). All groups were fed ad libitum. Body mass and food intake were monitored once a week. At the end of the experiment, all mice were fasted for $12 \mathrm{~h}$ and were sacrificed by cervical dislocation (all mice at the same day). Blood samples were collected into $\mathrm{K}_{3} \mathrm{H}$-EDTA coated tubes; plasma and erythrocytes were separated immediately by centrifugation $\left(3000 \mathrm{rpm}, 10 \mathrm{~min}, 10^{\circ} \mathrm{C}\right)$. After centrifugation and plasma removal, erythrocytes were washed three times with phosphate buffered saline (PBS, pH = 7.4). Liver, small intestine and colon were removed, washed with PBS containing a protease inhibitor cocktail and immediately frozen in liquid nitrogen. All biological samples were stored in a freezer at $-80^{\circ} \mathrm{C}$.

\section{Analysis of oxidative stress parameters in blood}

Selected parameters for evaluation of oxidative stress were determined using slight modifications of previously published methods: total level of SH groups (TSH) (9) and lipid peroxidation products such as malondialdehyde in plasma and in erythrocytes, GPx (10), CAT (11), GR (12), GST (13) and SOD (14) in red blood cells. All the parameters were expressed per grams of hemoglobin $(\mathrm{Hb})$ in erythrocytes or total proteins in the case of plasma (15).

\section{Preparation of subcellular fractions}

Microsomal and cytosolic fractions were obtained from liquid nitrogen-frozen liver, small intestine and large intestine of mice. All tissues were individually homogenized in $0.1 \mathrm{~mol} \mathrm{~L}^{-1}$ sodium phosphate buffer ( $\mathrm{pH}$ 7.4) using a Potter-Elvehjem homogenizer (Biotech International, UK). The subcellular fractions were isolated by differential centrifugation of the tissue homogenate. All fractions were stored at $-80^{\circ} \mathrm{C}$. Protein concentrations in subcellular fractions were assayed using the bicinchoninic acid assay according to the general manufacturer's protocol (Sigma-Aldrich).

\section{Enzyme assays}

Enzyme activities were assayed in the cytosolic and microsomal fractions from the homogenate of mouse liver, small intestine and large intestine. The enzyme activity assays (each performed in 4-8 replicates) were repeated three times. The amount of organic solvents in the final reaction mixtures did not exceed $1 \%(V / V)$. 
Assays of all enzymes were based on spectrophotometric detection of the products formed or detection of decreasing substrate/cofactor levels using a microplate reader Tecan Infinite M200 (Tecan, Switzerland) in cytosolic or microsomal fractions. Selected parameters for evaluation of oxidative stress were determined using slight modifications of previously published methods: cytosolic GST (13), peroxidase (Px) (16), GPx (17), catalase (CAT) (18), NQO (19), thioredoxin reductase (TrxR) and GR (20). The SOD assay was performed using a SOD Assay kit-WST according to the general manufacturer's protocol.

\section{Statistical analysis}

All calculations were done using Microsoft Excel and GraphPad Prism 6.02 (GraphPad Software, USA). One-way ANOVA was used for the statistical evaluation of the differences between the P-treated groups and the control. The differences were regarded as significant when $p<0.05$.

\section{RESULTS AND DISCUSSION}

The aim of the present in vivo study was to obtain detailed information about the effect of green tea catechins, in various dosage schemes, on oxidative stress status in mice. Commercially available Polyphenon, purified form of green tea extract, was used in the study to simulate consumption of the traditional green tea beverage and/or green tea extract in dietary supplements.

Oral administration was chosen as it corresponds to the common way of catechin intake. Three tested dosage schemes represented three possible situations: regular consumption of 2-3 cups of green tea daily (10 mg of catechins per $\mathrm{kg}$ of body mass, i.e., approx. $800 \mathrm{mg}$ per person) and over-dose consumption of green tea extracts (100 mg of catechins $\mathrm{kg}^{-1} \mathrm{bm}$, i.e., $8 \mathrm{~g}$ per person) in dietary supplements for a long (4 weeks) or short (3 days) period. While approx. $300 \mathrm{mg}$ of catechins were detected in one cup of green tea (21), one capsule of various dietary supplements may contain up to $1000 \mathrm{mg}$ of green tea catechins.

In our experiments, mice were chosen for this in vivo study as they are more similar to humans than rats in terms of catechin biotransformation (4). Seven-month-old mice served as the model of adult people who are more frequent users of natural dietary supplements (including green tea extracts). Conflicting reports were found in the literature regarding the activity and/or expression of antioxidant enzymes during aging (reviewed in ref. 1). Age-related changes may vary among tissues and may not exhibit the same intensity due to the biochemical activity of different tissues and the presence of different isoenzymes (1). Therefore, plasma, erythrocytes, liver, small intestine and large intestine were examined concurrently to obtain detailed information, since most of the previous studies on catechins' effects were focused only on hepatic or plasmatic enzymes. Moreover, poor absorption of catechins results in their low systemic bioavailability after oral administration but high intestinal and colonic mucosal exposure (22).

During all experiments, the body mass of mice and the amount of eaten pellets were monitored. The amount of eaten food per day was the same in all groups $(4.9 \pm 0.1 \mathrm{~g}$ per mouse). One mouse mass did not differ among groups ( $44 \pm 2 \mathrm{~g}$ ). 
At the end of the experiment, blood, liver, small intestine and large intestine were removed from each animal. Each tissue served for the determination of the activity of several antioxidant enzymes.

\section{Oxidative stress status of erythrocytes and plasma}

In mouse erythrocytes, the amount of malondialdehyde and specific activities of the following antioxidant enzymes were assayed: CAT, GPx, GR, GST and SOD. Results are shown in Table I. Among tested parameters, specific activity of SOD was significantly increased in the P-H28 group but decreased in the P-H3 group compared to the control. In addition, specific activity of CAT was markedly elevated in P-H28 as well as in P-L28 groups compared to the control. Other parameters did not significantly differ in P-treated mice when compared to the control.

In mouse plasma, the amount of $\mathrm{SH}$-groups and concentration of malondialdehyde were assayed and the results are shown in Table II. In all P-treated groups, the amount of $\mathrm{SH}$-groups was significantly increased. P-treatment in all dosage schemes did not affect malondialdehyde concentration in plasma.

In our experiment, catechins of the green tea extract in all tested dosage schemes increased significantly the amount of SH-groups in mouse plasma. However, no activity of antioxidant enzymes (with the exception of SOD and CAT) was increased by P treatment. Due to these facts, it follows the $\mathrm{P}$ in all tested doses improved only mildly the oxidative

Table I. Specific activities of antioxidant enzymes and malondialdehyde content (normalized to hemoglobin, $\mathrm{Hb}$, concentration) in erythrocytes from control mice and mice treated with Polyphenon $(P)$ at a high dose $(H)$ and low dose $(L)$ for 28 or 3 days

\begin{tabular}{lccrc}
\hline & Control $^{\mathrm{a}}$ & \multicolumn{1}{c}{ P-H3 $^{\mathrm{a}}$} & \multicolumn{1}{c}{ P-H28 } & \multicolumn{1}{c}{ P-L28 } \\
\hline Glutathione S-transferase $\left(\mu \mathrm{kat} \mathrm{g}^{\mathrm{a}} \mathrm{Hb}\right)$ & $0.75 \pm 0.10^{\mathrm{b}}$ & $0.65 \pm 0.13^{\mathrm{b}}$ & $0.85 \pm 0.11^{\mathrm{b}}$ & $0.87 \pm 0.19^{\mathrm{b}}$ \\
Glutathione peroxidase $\left(\mu \mathrm{kat} \mathrm{g}^{-1} \mathrm{Hb}\right)$ & $10.4 \pm 1.3^{\mathrm{b}}$ & $9.4 \pm 1.5^{\mathrm{b}, \mathrm{c}}$ & $8.3 \pm 1.0^{\mathrm{b}, \mathrm{c}}$ & $13.6 \pm 1.4^{\mathrm{b}, \mathrm{d}}$ \\
Glutathione reductase $\left(\mu \mathrm{kat} \mathrm{g}^{-1} \mathrm{Hb}\right)$ & $75.4 \pm 3.2^{\mathrm{b}}$ & $86.8 \pm 15.9^{\mathrm{b}}$ & $78.0 \pm 15.3^{\mathrm{b}}$ & $87.4 \pm 11.8^{\mathrm{b}}$ \\
Superoxide dismutase $\left(\mu \mathrm{kat} \mathrm{g}^{-1} \mathrm{Hb}\right)$ & $111.7 \pm 3.7^{\mathrm{b}}$ & $80.9 \pm 7.9^{\mathrm{c}}$ & $164.2 \pm 9.3^{\mathrm{d}}$ & $122.0 \pm 10.4^{\mathrm{b}}$ \\
Catalase $\left(\mu \mathrm{kat} \mathrm{g}^{-1} \mathrm{Hb}\right)$ & $6.0 \pm 0.1^{\mathrm{b}}$ & $5.7 \pm 0.3^{\mathrm{b}}$ & $6.8 \pm 0.2^{\mathrm{c}}$ & $6.8 \pm 0.1^{\mathrm{c}}$ \\
Malondialdehyde $\left(\mathrm{mmol} \mathrm{g}{ }^{-1} \mathrm{Hb}\right)$ & $363 \pm 56^{\mathrm{b}}$ & $366 \pm 68^{\mathrm{b}}$ & $382 \pm 35^{\mathrm{b}}$ & $374 \pm 72^{\mathrm{b}}$ \\
\hline
\end{tabular}

${ }^{\mathrm{a}}$ Mean $\pm \mathrm{SD}(n=3)$.

b,c,d Groups with different letters vary significantly $(p \leq 0.05)$.

Table II. Content of SH-group and malondialdehyde (normalized to protein concentration) in plasma from control mice and mice treated with Polyphenon $(P)$ at a high dose $(H)$ and low dose $(L)$ for 28 or 3 days

\begin{tabular}{lcccc}
\hline & Control $^{\mathrm{a}}$ & P-H3 $^{\mathrm{a}}$ & P-H28 & P-L28 $^{\mathrm{a}}$ \\
\hline SH-group $\left(\mu \mathrm{mol} \mathrm{g}{ }^{-1}\right.$ proteins $)$ & $67 \pm 3^{\mathrm{b}}$ & $100 \pm 3^{\mathrm{c}}$ & $81 \pm 2^{\mathrm{d}}$ & $112 \pm 7^{\mathrm{e}}$ \\
Malondialdehyde $\left(\mu \mathrm{mol} \mathrm{g}{ }^{-1}\right.$ proteins $)$ & $739 \pm 99^{\mathrm{b}}$ & $727 \pm 20^{\mathrm{b}}$ & $778 \pm 61^{\mathrm{b}}$ & $838 \pm 11^{\mathrm{b}}$ \\
\hline
\end{tabular}

${ }^{\mathrm{a}}$ Mean $\pm \mathrm{SD}(n=4)$.

b,c,d,e Groups with different letters vary significantly $(p \leq 0.05)$. 
stress status of mice. On the other hand, the oxidative stress in plasma and erythrocytes was not increased after Polyphenon treatment. This indicates that green tea catechins, even at high doses, have no pro-oxidative effects in erythrocytes and plasma. In agreement with this finding, a lack of chronic toxicity of the catechin mixture up to $2.5 \mathrm{~g} \mathrm{~kg}^{-1}$ per day was documented in rats (23).

\section{Antioxidant enzymes in liver, small intestine and large intestine}

Activities of antioxidant enzymes CAT, SOD, GR, GPx, GST, NQO, peroxidase (Px) and thioredoxin reductase ( $\operatorname{Tr} x \mathrm{R})$ were assayed using specific substrates in cytosolic fractions obtained from mouse liver, small intestine and large intestine. In all these tissues, the activities of all antioxidant enzymes were detectable. The results are summarized in Table III.

Table III. Specific activities of selected antioxidant enzymes in liver, small intestine and large intestine from control mice and mice treated with Polyphenon $(P)$ at a high dose $(H)$ and low dose $(L)$ for 28 or 3 days

\begin{tabular}{|c|c|c|c|c|c|}
\hline Enzyme & Tissue & Control $^{a}$ & $\mathrm{P}-\mathrm{H}^{\mathrm{a}}$ & $\mathrm{P}-\mathrm{H} 28^{\mathrm{a}}$ & P-L28 \\
\hline $\begin{array}{l}\text { Peroxidase } \\
\text { (nmol min }{ }^{-1} \mathrm{mg}^{-1} \text { of protein) }\end{array}$ & $\begin{array}{l}\text { Liver } \\
\text { Small intestine } \\
\text { Large intestine }\end{array}$ & $\begin{array}{l}4.01 \pm 0.45^{\mathrm{b}} \\
1.03 \pm 0.21^{\mathrm{b}} \\
2.02 \pm 0.71^{\mathrm{b}}\end{array}$ & $\begin{array}{c}4.62 \pm 1.07^{\mathrm{b}} \\
1.25 \pm 0.16^{\mathrm{b}} \\
3.2 \pm 0.7^{\mathrm{b}}\end{array}$ & $\begin{array}{l}4.71 \pm 0.31^{\mathrm{b}} \\
0.97 \pm 0.12^{\mathrm{b}} \\
2.19 \pm 0.74^{\mathrm{b}}\end{array}$ & $\begin{array}{l}3.99 \pm 0.15^{\mathrm{b}} \\
0.85 \pm 0.23^{\mathrm{b}} \\
2.06 \pm 0.6^{\mathrm{b}}\end{array}$ \\
\hline $\begin{array}{l}\text { Glutathione peroxidase } \\
\text { (nmol min } \mathrm{mg}^{-1} \text { of protein) }\end{array}$ & $\begin{array}{l}\text { Liver } \\
\text { Small intestine } \\
\text { Large intestine }\end{array}$ & $\begin{array}{l}394 \pm 2.0^{\mathrm{b}} \\
79.9 \pm 3.0^{\mathrm{b}, \mathrm{c}} \\
80.8 \pm 5.3^{\mathrm{b}}\end{array}$ & $\begin{array}{c}330 \pm 23^{\mathrm{b}} \\
74.1 \pm 1.5^{\mathrm{b}} \\
80.6 \pm 8.3^{\mathrm{b}}\end{array}$ & $\begin{array}{r}364 \\
82.9 \\
73.4\end{array}$ & $\begin{array}{c}418 \pm 63^{\mathrm{b}} \\
77.2 \pm 5.2^{\mathrm{b}, \mathrm{c}} \\
71.4 \pm 2.5^{\mathrm{b}}\end{array}$ \\
\hline $\begin{array}{l}\text { Catalase } \\
\left(\mu \mathrm{mol} \mathrm{min}^{-1} \mathrm{mg}^{-1} \text { of protein }\right)\end{array}$ & $\begin{array}{l}\text { Liver } \\
\text { Small intestine } \\
\text { Large intestine }\end{array}$ & $\begin{array}{r}18.0 \pm 0.3^{\mathrm{b}} \\
12.3 \pm 1.0^{\mathrm{b}} \\
9.0 \pm 0.7^{\mathrm{b}}\end{array}$ & $\begin{array}{r}17.9 \pm 4.0^{\mathrm{b}} \\
11.8 \pm 0.8^{\mathrm{b}} \\
9.6 \pm 0.6^{\mathrm{b}}\end{array}$ & $\begin{array}{r}16.7 \pm 3.5^{\mathrm{b}} \\
12.7 \pm 3.0^{\mathrm{b}} \\
8.3 \pm 3.1^{\mathrm{b}}\end{array}$ & $\begin{array}{r}18.8 \pm 3.6^{\mathrm{b}} \\
11.0 \pm 0.7^{\mathrm{b}} \\
5.2 \pm 2.2^{\mathrm{b}}\end{array}$ \\
\hline $\begin{array}{l}\text { Superoxide dismutase } \\
\text { (nmol } \mathrm{min}^{-1} \mathrm{mg}^{-1} \text { of protein) }\end{array}$ & $\begin{array}{l}\text { Liver } \\
\text { Small intestine } \\
\text { Large intestine }\end{array}$ & $\begin{array}{l}11.2 \pm 0.2^{\mathrm{b}} \\
16.4 \pm 0.8^{\mathrm{b}, \mathrm{c}} \\
18.5 \pm 0.1^{\mathrm{b}}\end{array}$ & $\begin{array}{l}10.4 \pm 0.1^{\mathrm{c}} \\
14.8 \pm 0.6^{\mathrm{b}} \\
18.2 \pm 0.3^{\mathrm{b}}\end{array}$ & $\begin{array}{l}10.8 \pm 0.1^{\mathrm{d}} \\
16.6 \pm 0.6^{\mathrm{c}} \\
20.1 \pm 0.9^{\mathrm{c}}\end{array}$ & $\begin{array}{l}11.6 \pm 0.1^{\mathrm{e}} \\
17.8 \pm 0.8^{\mathrm{c}} \\
19.1 \pm 0.7^{\mathrm{b}, \mathrm{c}}\end{array}$ \\
\hline $\begin{array}{l}\text { Glutathione reductase } \\
\text { (nmol } \mathrm{min}^{-1} \mathrm{mg}^{-1} \text { of protein) }\end{array}$ & $\begin{array}{l}\text { Liver } \\
\text { Small intest } \\
\text { Large intest }\end{array}$ & $\begin{array}{l}23.5 \pm 1.7^{\mathrm{b}} \\
56.0 \pm 1.5^{\mathrm{b}} \\
11.1 \pm 0.7^{\mathrm{b}, \mathrm{c}}\end{array}$ & $\begin{array}{l}23.3 \pm 1.5^{\mathrm{b}} \\
48.5 \pm 0.6^{\mathrm{c}} \\
10.8 \pm 0.3^{\mathrm{b}}\end{array}$ & $\begin{array}{l}23.5 \pm 0.5^{\mathrm{b}} \\
55.1 \pm 1.3^{\mathrm{b}} \\
12.4 \pm 0.5^{\mathrm{c}}\end{array}$ & $\begin{array}{l}23.9 \pm 1.0^{\mathrm{b}} \\
58.7 \pm 0.8^{\mathrm{b}} \\
11.7 \pm 0.5^{\mathrm{b}, \mathrm{c}}\end{array}$ \\
\hline $\begin{array}{l}\text { Glutathione S-transferease } \\
\text { (nmol min }{ }^{-1} \mathrm{mg}^{-1} \text { of protein) }\end{array}$ & $\begin{array}{l}\text { Liver } \\
\text { Small intestine } \\
\text { Large intestine }\end{array}$ & $\begin{array}{l}885 \pm 36^{\mathrm{b}} \\
284 \pm 30^{\mathrm{b}, \mathrm{d}} \\
267 \pm 25^{\mathrm{b}}\end{array}$ & $\begin{array}{l}787 \pm 29^{\mathrm{b}} \\
242 \pm 27^{\mathrm{b}, \mathrm{c}} \\
259 \pm 20^{\mathrm{b}}\end{array}$ & $\begin{array}{l}867 \pm 45^{b} \\
214 \pm 24^{c} \\
233 \pm 22^{b}\end{array}$ & $\begin{array}{l}870 \pm 50^{\mathrm{b}} \\
343 \pm 24^{\mathrm{d}} \\
223 \pm 23^{\mathrm{b}}\end{array}$ \\
\hline $\begin{array}{l}\text { ductase } \\
\mathrm{g}^{-1} \text { of protein) }\end{array}$ & $\begin{array}{l}\text { Liver } \\
\text { Small intestine } \\
\text { Large intestine }\end{array}$ & $\begin{array}{l}19.1 \pm 2.3^{\mathrm{b}} \\
37.0 \pm 0.7^{\mathrm{b}} \\
22.4 \pm 0.6^{\mathrm{b}}\end{array}$ & $\begin{array}{l}18.7 \pm 1.9^{\mathrm{b}} \\
35.1 \pm 1.3^{\mathrm{b}, \mathrm{c}} \\
21.6 \pm 0.5^{\mathrm{b}}\end{array}$ & $\begin{array}{l}20.2 \pm 2.4^{\mathrm{b}} \\
32.3 \pm 1.5^{\mathrm{c}} \\
18.6 \pm 0.4^{\mathrm{c}}\end{array}$ & $\begin{array}{l}17.6 \pm 2.5^{b} \\
40.6 \pm 0.8^{d} \\
18.8 \pm 0.3^{c}\end{array}$ \\
\hline $\begin{array}{l}\mathrm{NAD}(\mathrm{P}) \mathrm{H} \text { quinone reductase } \\
\text { (nmol min } \mathrm{mg}^{-1} \text { of protein) }\end{array}$ & $\begin{array}{l}\text { Liver } \\
\text { Small intestine } \\
\text { Large intestine }\end{array}$ & $\begin{array}{r}10.6 \pm 0.4^{\mathrm{b}} \\
9.6 \pm 1.9^{\mathrm{b}} \\
13.2 \pm 1.4^{\mathrm{b}}\end{array}$ & $\begin{array}{l}10.1 \pm 0.7^{\mathrm{b}} \\
14.9 \pm 1.2^{\mathrm{c}} \\
25.8 \pm 1.7^{\mathrm{c}}\end{array}$ & $\begin{array}{r}11.5 \pm 0.9^{\mathrm{b}} \\
9.3 \pm 0.4^{\mathrm{b}} \\
8.8 \pm 2.6^{\mathrm{b}}\end{array}$ & $\begin{array}{r}18.3 \pm 1.0^{\mathrm{c}} \\
14.6 \pm 1.2^{\mathrm{c}} \\
9.1 \pm 3.5^{\mathrm{b}}\end{array}$ \\
\hline
\end{tabular}

${ }^{\mathrm{a}}$ Mean $\pm \operatorname{SD}(n=3)$.

$b, c, d, e$ Groups with different letters vary significantly ( $p \leq 0.05)$. 
Comparison of the obtained activities in P-treated mice and in controls revealed that P-treatment did not lead to a significant increase in most antioxidant enzymes (with the exception of NQO, SOD and TrxR) in any tissue. Moreover, short-term P-treatment (P-H3 group) caused a significant decrease in hepatic SOD activity and intestinal GR activity. In the P-H28 group, activities of SOD (liver), GST (small intestine) and TrxR (small and large intestine) were significantly decreased. Specific activity of $\operatorname{Tr} x \mathrm{R}$ was markedly reduced also in the large intestine of mice receiving low doses of $P$ for 28 days.

Hepatic NQO activity was significantly increased in the P-L28 group compared to the control. In small intestine, NQO was significantly increased in P-L28 and P-H3 groups, while only short-term treatment (P-H3) led to NQO increase in large intestine.

In the P-L28 group, which simulates regular green tea consumption, NQO activity was significantly increased in liver as well as in small intestine. As NQO converts quinones to hydroquinones and reduces oxidative cycling, its increase is considered chemopreventive (24). Hence, elevation of NQO activity is probably beneficial for green tea catechins consumers. In mice from group P-H28, which represents a chronic overdose by dietary supplements with high content of green tea catechins, NQO, did not differ from the controls. On the other hand, the catechin-enriched diet $(0.2 \%, \mathrm{~m} / \mathrm{m})$ administered to rats for 3 weeks lowered hepatic NQO activity by $26 \%$ (7), but oral feeding of green tea catechins in drinking water $(0.2 \%, \mathrm{~m} / \mathrm{V})$ for 30 days raised significantly the activities of NQO in mouse liver (25).

Short-term (3-days) overdose intake of green tea catechins (group P-H3) led to augmentation of intestinal NQO activities, but hepatic SOD and intestinal GR activities were significantly diminished. On the other hand, long-term (28-days) overdose consumption of green tea catechins (group P-H28) caused reduction in intestinal GST and TrxR activities. Decrease in GST activity could reflect GST inhibition by catechins, which was observed in vitro (26). These results warn that overdose consumption of catechins could significantly decrease detoxification of xenobiotics, especially in small intestine, with all the possible consequences.

Consistent with the fact that catechins are considered to be potential inducers of antioxidant enzymes, an increase in some of them (NQO, TrxR and SOD) was observed in our study after Polyphenon administration to mice. These results partly correspond with the conclusions of the previously published study that the catechin-enriched diet $(0.2 \%$, $\mathrm{m} / \mathrm{m}$ ) administered for 3 weeks to rats did not affect the activity of hepatic CAT, GPx, GST and SOD (7). Conversely, oral feeding of a polyphenolic fraction isolated from green tea extract in drinking water $(0.2 \%, \mathrm{~m} / \mathrm{V})$ for 30 days elevated significantly the activities of GPx, CAT, GR and GST in mouse small intestine and liver (26). Treatment of rats with a 1:1 mixture of epicatechin and catechin $\left(23 \mathrm{mg} \mathrm{kg}^{-1} \mathrm{bm}\right.$, i.p. for 10 days) led to a significant decrease in GPx activity and an increase in SOD activity in blood and urine (27) but the predictive value of this experimental set-up with intraperitoneal route of administration is questionable. Although catechins are generally believed to improve the oxidative stress status, analysis of the results of 31 controlled ex vivo and in vivo interventional studies in humans showed limited evidence that regular consumption of green tea (0.6-1.5 L per day) may increase antioxidant capacity and reduce lipid peroxidation (28). 


\section{CONCLUSIONS}

In conclusion, the increased content of SH-group in P-treated mice indicates the antioxidant ability of catechins. No pro-oxidative effects of the green tea extract (in all tested dosage schemes) were observed in erythrocytes and plasma. P at low doses led to an increase of NQO, SOD and TrxR activities, which may improve chemoprevention. On the other hand, $\mathrm{P}$ at high doses inhibits some antioxidant enzymes (SOD, GR, GST, TrxR). Based on these facts, consumption of catechins in reasonable amounts (i.e., regular drinking of green tea) seems to be safe and beneficial. On the other hand, consumption of extremely high doses of catechins in dietary supplements may disturb the oxidative balance via inhibition of certain antioxidant enzymes.

Acknowledgements. - This work was supported by the Czech Science Foundation (Centre of Excellence, grant number P303/12/G163) and by the European Social Fund and the state budget of the Czech Republic (Project no. CZ.1.07/2.3.00/30.0022).

\section{REFERENCES}

1. M. Giergiel, M. Lopucki, N. Stachowicz and M. Kankofer, The influence of age and gender on antioxidant enzyme activities in humans and laboratory animals, Aging Clin. Exp. Res. 24 (2012) 561-569; DOI: 10.3275/8587.

2. C. S. Yang and E. Pan, The effects of green tea polyphenols on drug metabolism, Expert Opin. Drug Metab. Toxicol. 8 (2012) 677-689; DOI: 10.1517/17425255.2012.681375.

3. I. Rodeiro, M. T. Donato, A. Lahoz, G. Garrido, R. Delgado and M. J. Gómez-Lechón, Interactions of polyphenols with the p450 system: possible implications on human therapeutics, Mini Rev. Med. Chem. 8 (2008) 97-106; DOI: 10.2174/138955708783498131.

4. J. D. Lambert, S. Sang and C. S. Yang, Biotransformation of green tea polyphenols and the biological activities of those metabolites, Mol. Pharm. 4 (2007) 819-825; DOI: 10.1021/mp700075m.

5. J. D. Lambert, S. Sang, A. Y. Lu and C. S. Yang, Metabolism of dietary polyphenols and possible interactions with drugs, Curr. Drug Metab. 8 (2007) 499-507; DOI: 10.2174/138920007780866870.

6. H. K. Na and Y. J. Surh, Modulation of Nrf2-mediated antioxidant and detoxifying enzyme induction by the green tea polyphenol EGCG, Food Chem. Toxicol. 46 (2008) 1271-1278; DOI: 10.1016/j. fct.2007.10.006.

7. H. Wiegand, C. Boesch-Saadatmandi, I. Regos, D. Treutter, S. Wolffram and G. Rimbach, Effects of quercetin and catechin on hepatic glutathione-S transferase (GST), NAD(P)H quinone oxidoreductase 1 (NQO1), and antioxidant enzyme activity levels in rats, Nutr. Cancer 61 (2009) 717-722; DOI: 10.1080/01635580902825621.

8. P. Matoušková, H. Bártiková, I. Boušová, B. Szotáková, J. Martin, J. Skorkovská, V. Hanušová, V. Tománková, E. Anzenbacherová, B. Lišková, P. Anzenbacher and L. Skálová, Effect of defined green tea extract in various dosage schemes on drug-metabolizing enzymes in mice in vivo, J. Funct. Foods 10 (2014) 327-335; DOI: 10.1016/j.jff.2014.06.026.

9. M. L. Hu, Measurement of protein thiol groups and glutathione in plasma, Methods Enzymol. 233 (1994) 380-385; DOI: 10.1016/S0076-6879(94)33044-1.

10. A. Wendel, Glutathione peroxidase, Methods Enzymol. 77 (1981) 325-333; DOI: 10.1016/S00766879(81)77046-0.

11. A. C. Maehly and B. Chance, The assay of catalases and peroxidases, Methods Biochem. Anal. 1 (1954) 357-424; DOI: 10.1002/9780470110171.ch14. 
12. I. Carlberg and B. Mannervik, Glutathione reductase, Methods Enzymol. 113 (1985) 484-490; DOI: 10.1016/S0076-6879(85)13062-4.

13. W. H. Habig and W. B. Jakoby, Glutathione S-transferases (rat and human), Methods Enzymol. 77 (1981) 218-231; DOI: 10.1016/S0076-6879(81)77029-0.

14. L. Flohé and F. Otting, Superoxide dismutase assays, Methods Enzymol. 105 (1984) 93-104; DOI: 10.1016/S0076-6879(84)05013-8.

15. M. M. Bradford, A rapid and sensitive method for the quantitation of microgram quantities of protein utilizing the principle of protein-dye binding, Anal. Biochem. 72 (1976) 248-254; DOI: 10.1016/0003-2697(76)90527-3.

16. A. Molaei Rad, H. Ghourchian, A. A. Moosavi-Movahedi, J. Hong and K. Nazari, Spectrophotometric assay for horseradish peroxidase activity based on pyrocatechol-aniline coupling hydrogen donor, Anal. Biochem. 362 (2007) 38-43; DOI: 10.1016/j.ab.2006.11.035.

17. D. E. Handy, E. Lubos, Y. Yang, J. D. Galbraith, N. Kelly, Y. Y. Zhang, J. A. Leopold and J. Loscalzo, Glutathione peroxidase-1 regulates mitochondrial function to modulate redox-dependent cellular responses, J. Biol. Chem. 284 (2009) 11913-11921; DOI: 10.1074/jbc.M900392200.

18. L. Góth, A simple method for determination of serum catalase activity and revision of reference range, Clin. Chim. Acta 196 (1991) 143-151; DOI: 10.1016/0009-8981(91)90067-M.

19. J. J. Cullen, M. M. Hinkhouse, M. Grady, A. W. Gaut, J. Liu, Y. P. Zhang, C. J. Weydert, F. E. Domann and L. W. Oberley, Dicumarol inhibition of NADPH:Quinone oxidoreductase induces growth inhibition of pancreatic cancer via a superoxide-mediated mechanism, Cancer Res. 63 (2003) 55135520.

20. M. Bonilla, A. Denicola, S. V. Novoselov, A. A. Turanov, A. Protasio, D. Izmendi, V. N. Gladyshev and G. Salinas, Platyhelminth mitochondrial and cytosolic redox homeostasis is controlled by a single thioredoxin glutathione reductase and dependent on selenium and glutathione, J. Biol. Chem. 283 (2008) 17898-17907; DOI: 10.1074/jbc.M710609200.

21. M. Renouf, C. Marmet, P. A. Guy, M. Beaumont, M. Lepage, G. Williamson and F. Dionisi, Doseresponse plasma appearance of green tea catechins in adults, Mol. Nutr. Food Res. 57 (2013) 833839; DOI: 10.1002/mnfr.201200512.

22. G. W. Dryden, A. Lam, K. Beatty, H. H. Qazzaz and C. J. Mcclain, A pilot study to evaluate the safety and efficacy of an oral dose of (-)-epigallocatechin-3-gallate-rich Polyphenon E in patients with mild to moderate ulcerative colitis, Inflamm. Bowel Dis. 19 (2013) 1904-1912; DOI: 10.1097/ MIB.0b013e31828f5198.

23. M. Yoshida, M. Takahashi, K. Inoue, D. Nakae and A. Nishikawa, Lack of chronic toxicity and carcinogenicity of dietary administrated catechin mixture in Wistar Hannover GALAS rats, J. Toxicol. Sci. 36 (2011) 297-311; DOI: 10.2131/jts.36.297.

24. M. Cuendet, C. P. Oteham, R. C. Moon and J. M. Pezzuto, Quinone reductase induction as a biomarker for cancer chemoprevention, J. Nat. Prod. 69 (2006) 460-463; DOI: 10.1021/np050362q.

25. S. G. Khan, S. K. Katiyar, R. Agarwal and H. Mukhtar, Enhancement of antioxidant and phase II enzymes by oral feeding of green tea polyphenols in drinking water to SKH-1 hairless mice: possible role in cancer chemoprevention, Cancer Res. 52 (1992) 4050-4052.

26. I. Boušová, J. Hájek, J. Dršata and L. Skálová, Naturally occurring flavonoids as inhibitors of purified cytosolic glutathione S-transferase, Xenobiotica 42 (2012) 872-879; DOI: 10.3109/00498254. 2012.670737.

27. Y. V. Simos, I. I. Verginadis, I. K. Toliopoulos, A. P. Velalopoulou, I. V. Karagounis, S. C. Karkabounas and A. M. Evangelou, Effects of catechin and epicatechin on superoxide dismutase and glutathione peroxidase activity, in vivo, Redox Rep. 17 (2012) 181-186; DOI: 10.1179/1351000212y. 0000000020.

28. S. Ellinger, N. Müller, P. Stehle and G. Ulrich-Merzenich, Consumption of green tea or green tea products: is there an evidence for antioxidant effects from controlled interventional studies?, Phytomedicine 18 (2011) 903-915; DOI: 10.1016/j.phymed.2011.06.006. 